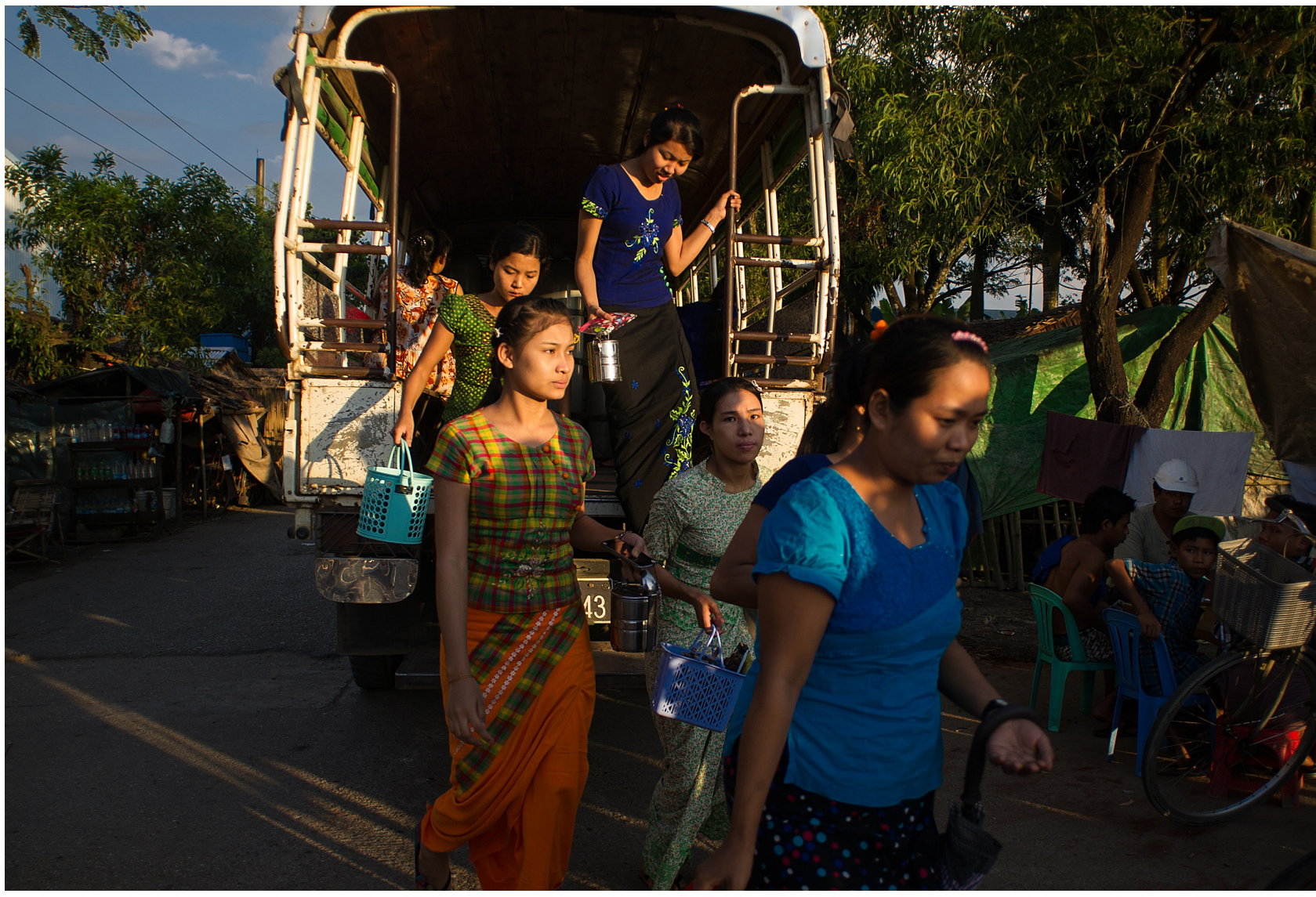

Factory workers step out of their shuttle bus as their shift ends. Hlaing Thar Yar Industrial Zone, Yangon, November 2015. Photo: Kaung Htet/Oxfam

\title{
UNDERPAID AND UNDERVALUED: HOW INEQUALITY DEFINES WOMEN'S WORK IN ASIA
}

Rising economic inequality across Asia is threatening poverty reduction and slowing down the fight against gender inequality. Although the region has experienced economic growth, the bottom 70 percent have seen their income share fall while the share for the top 10 percent has increased rapidly. Low wages and a lack of rights at work, particularly for women, are at the heart of this scandal. At the same time, women are subsidizing the economy with a disproportionate responsibility for unpaid care work. Achieving living wages and recognizing, redistributing and reducing unpaid care work could support both economic and gender equality in Asia and should be prioritized by both governments and businesses. 
For women across Asia, access to decent work and a living wage represents a fundamental pathway out of poverty, and one of the best ways to counter the dangerous tide of growing economic inequality. Yet in recent decades, working people, in rich and poor countries alike, have received a smaller and smaller slice of the economic pie, while those who own capital have seen their assets grow disproportionately. Low wages for the majority of people, and particularly for women, are at the heart of this scandal. At the same time, women continue to carry out the majority of unpaid care and domestic work, which is essential to keep economies functioning but is unrecognized and undermined in policy making.

On average in Asia women earn between 70 and 90 percent of what men earn. ${ }^{1}$ One reason for this is that women are disproportionately concentrated in the lowest paid roles and in informal work. 75 percent of women's work in Asia is in the informal economy, without access to benefits such as sick pay or maternity leave. ${ }^{2}$ Pervasive gender inequality means that women's work is devalued, and women are less likely to be empowered to claim their labour rights. Women also carry out around 2.5 times the amount of unpaid care work that men do, and globally this work is worth around $\$ 10$ trillion a year. $^{3}$

Women's economic empowerment is a critical factor in achieving gender equality and in supporting wider development goals. It offers one entry point into women's empowerment, which also includes social and political dimensions. To achieve it, not only must more women have opportunities to take up paid work, but the quality of jobs available to them must improve - along with their rights and decision making power. Increasing women's access to decent work with a living wage and secure contract is a key way to achieve this. However, current economic policies undermine these goals, instead creating a race to the bottom on wages and working conditions in order for businesses to keep costs down.

In recent decades, Asia has experienced high and sustained levels of economic growth. Between 1990 and 2015, the region's economy grew on average six percent a year. ${ }^{4} \mathrm{~A}$ path of inclusive sustainable development would see this fairly benefit the poorest and address social inequalities and exclusion. However, across Asia, an economic model has been pursued which has instead driven a rise in extreme economic inequality, slowing down progress towards eliminating poverty and deepening other forms of inequality, including gender inequality.

Reversing these dangerous trends and achieving women's economic equality will require a range of actions from all stakeholders. The current economic model drives economic inequality and must be reformed to ensure economic growth benefits everyone fairly. Challenging deepseated gender inequalities that affect all aspects of women's lives, beyond their economic participation, will be essential alongside this. 
This paper looks at two actions that can be taken which would support both gender and economic equality: achieving living wages and addressing unpaid care work. Currently, where minimum wages are in place they are often set too low to constitute a living wage, and they are not adequately enforced. Oxfam's research with women workers in Asia shows that although they are working long hours in industries which are profitable for others, their wages are not enough to live on and they don't have the security they need. Governments could work with unions and labour movements to move towards living wages and full rights at work for all workers.

Women's heavy and disproportionate responsibility for unpaid care work reduces their choices and decision making power, and means that women are subsidizing the economy for free. Recognizing this contribution through better data collection and investments in care work are crucial. Social protection measures and investments in public services and infrastructure can reduce and redistribute it. These measures require governments to raise the funds, predominately through progressive taxation, in order to be able to invest in women's economic equality. With these policies and practices in place, governments and businesses can support Asia to get on the right track to economic equality and to better work and wages for women.

\section{ECONOMIC INEQUALITY IN ASIA}

The average Gini coefficient in Asia, which correlates to the distribution of income within a country, rose at twice the pace of the rest of the world between 1990 and 2013, and even faster in countries with the largest populations such as Indonesia, India and China. ${ }^{5}$ Emerging economies like these have seen income inequality rise at a rapid pace; this shows that countries experiencing the highest patterns of growth are not always passing on these benefits fairly. The IMF has found that the rise in extreme inequality in the region has largely been driven by increases in the incomes of those at the top of the economy. ${ }^{6}$ Between 1990 and 2010, the bottom 70 percent of the population's share of income has decreased, while the top 10 percent have seen large gains. ${ }^{7}$ These patterns are not unique to Asia: they are part of a global trend towards the concentration of wealth in the hands of a small elite. ${ }^{8}$

The trend of growing inequality across Asia is deeply gendered. Overwhelmingly, the richest in society are men, while women continue to be concentrated in the lowest paid and most insecure jobs. Women are systematically paid low wages to make products that often end up on the tables, in the wardrobes and on the feet of people in developed economies. The reasons for this are complex. Pervasive gender inequality means that women's work is devalued, and women are less likely to be empowered to claim their labour rights. This means women are more likely to have these rights abused, often with devastating consequences. ${ }^{9}$ Women also continue to carry out the majority of unpaid care work, which creates time poverty and reduces their ability to make choices about paid work opportunities. 
Although Asia stands to gain economically from increasing women's involvement in the labour market, ${ }^{10}$ women themselves, particularly the poorest women and girls, have so far not benefitted fairly from the growth that they are making possible. Once set in motion, this trend becomes a vicious circle; countries with higher income inequality also tend to be countries that have higher gender inequality. ${ }^{11}$

Box 1: Frameworks for inclusive development - the UN Framework on Business and Human Rights and the Global Goals

The UN Framework on Business and Human Rights, and the associated Guiding Principles, ${ }^{12}$ have since 2011 become an authoritative global reference point for business to address adverse human rights impacts. The framework sets down two challenges for a company to address living wages in its supply chain: 1 . to understand the root causes that may give rise to adverse impacts on wages; and 2. to identify how a company can use its influence to reduce these adverse impacts. ${ }^{13}$

The Global Goals (Sustainable Development Goals) launched in 2015 brought a renewed focus on eradicating poverty in all its forms and dimensions. This briefing paper relates particularly to Goal 5 (Achieve gender equality and empower all women and girls); Goal 8 (Promote inclusive and sustainable economic growth, employment and decent work for all) and Goal 10 (Reduce inequality within and among countries). ${ }^{14}$

\section{GENDER INEQUALITY IN THE ECONOMY: TRENDS}

A number of countries in Asia, including Cambodia and Vietnam, mandate against discrimination in hiring based on gender, and in others such as Bangladesh and the Philippines, the law mandates that work of equal value should receive equal pay. ${ }^{15}$ However, there remains a wide chasm between these commitments on paper and achieving economic equality between men and women. Inequality of wages and opportunities between men and women persists throughout the region and beyond.

Across Asia, women tend to be concentrated in low-paid and insecure work. ${ }^{16} 75$ percent of women's work is in the informal sector, without access to benefits such as sick pay, maternity leave or pensions. ${ }^{17}$ They also carry out the majority of unpaid care work - very often, this goes unrecognized by society and excluded from economic statistics.

Economic inequality between men and women is driven by deeply held attitudes and beliefs which reduce women's opportunities and autonomy. This paper discusses how this is also reinforced by the dominant economic model and government policies, which have reduced the power of the labour force and failed to create investment in the care economy. Industry practices have also often resulted in the failure to pay living wages, which may be good for profits but is bad for the many women concentrated in the lowest paid roles. 


\section{OPPORTUNITIES FOR PAID WORK}

Women's share in total employment has remained comparatively high (in global terms) across Asia. But more women in work does not necessarily mean more gender equality. Women and men across Asia continue to experience gaps in status, pay and access to rights in the workplace.

Figure 1: Women's share in total employment across the Asia region (selected countries), 2003 and 2015, percentages, ILO estimations



Source: ILO STAT database ${ }^{18}$

Gender gaps in employment are different across the region: in SouthEast Asian countries, the gap between the percentage of women and men working is lower than in South Asian countries. In 2015, in Lao PDR, for every 100 men employed, ${ }^{19}$ there were 105 employed women; in Sri Lanka the ratio was 100 to 42 , and in Pakistan, 100 to $27 .{ }^{20}$ In countries where women's economic participation is at much lower rates than men, strong cultural norms are a factor. ${ }^{21}$ In countries with high female employment but where small-scale, household farming is prevalent, for example Lao PDR, often the higher rate is due to women being engaged in their household's farming activities. ${ }^{22}$ When countries start to industrialize, women's participation rates often fall as they do not take up the paid work opportunities created outside the home at the same rates as men. ${ }^{23}$

\section{THE IMPORTANCE OF DECENT WORK ON A LIVING WAGE}

Increasing women's participation in the paid economy can have both positive effects for women themselves and the wider economy, by supporting women's incomes and autonomy, and economic growth. However, for women to benefit fairly from new opportunities, this needs to be accompanied by broader changes towards gender equality, and their work needs to be grounded in secure jobs paying a living wage. 
Secure employment contracts confer multiple benefits on workers. They enable people to claim entitlements from employers, to claim social welfare from the government, and they make workers more visible, which means it is more likely that they will be engaged with and supported by trade unions, labour organizations and NGOs. Secure employment contracts can also act as collateral, allowing people to obtain housing and bank accounts: with this they bring the capacity to plan and save, increasing a household's resilience to shocks.

Figure 2: The importance of an employment contract

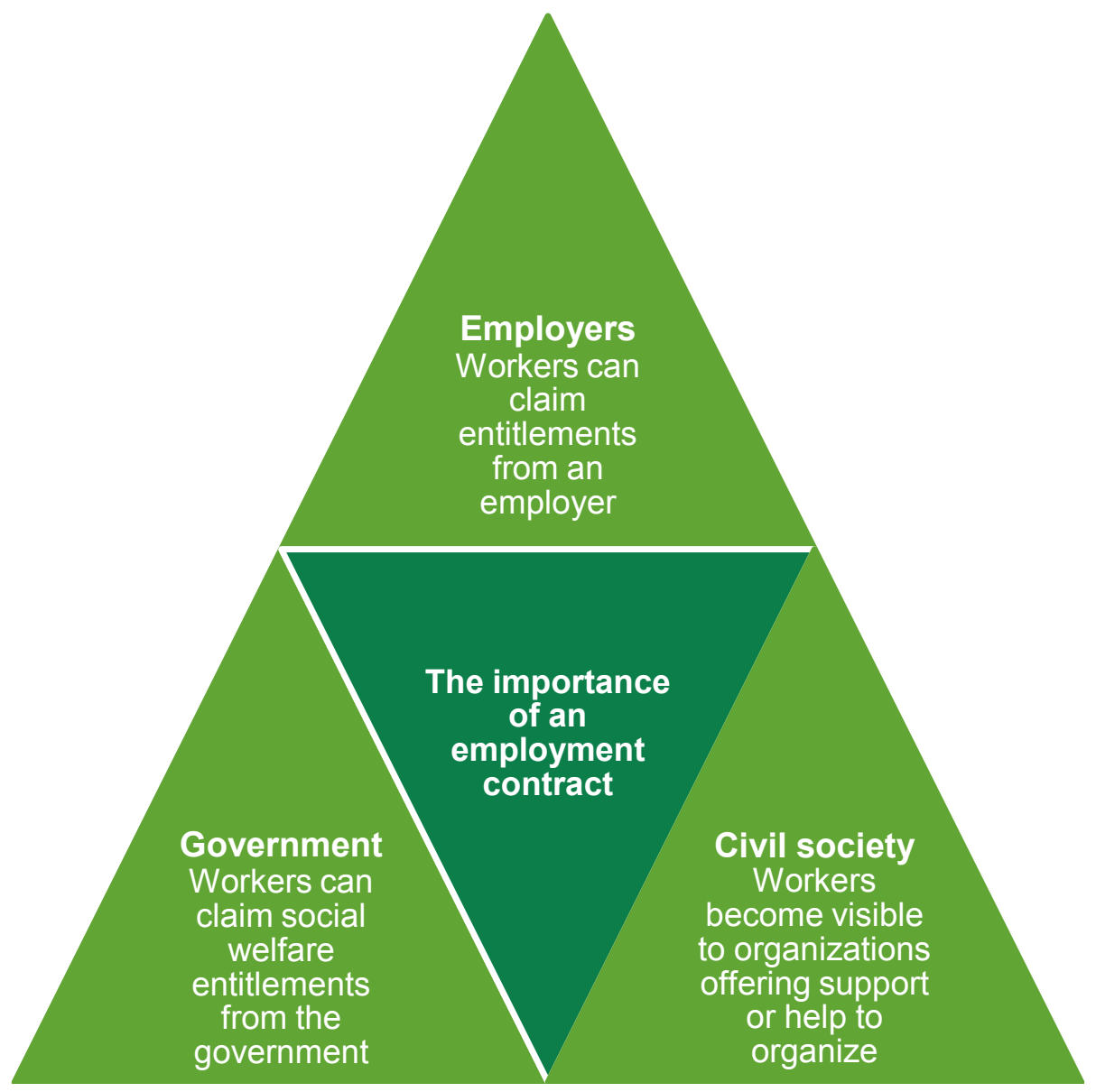

Having an employment contract is vital for a worker, for three reasons.

Globally, women and men in manufacturing sectors, including the garment sector, are often put on short-term contracts which make it impossible to plan for the future or the unexpected. Ensuring that workers have access to secure, preferably open-ended contracts that allow them to plan for the future, and do not undermine their ability to join a union is an essential part of building a stable, prosperous and productive workforce in which paid and unpaid roles can be fulfilled without causing harm to workers and their families. Women in the region, on average, are more likely than men to be in informal and insecure employment. ${ }^{24}$

In some low income countries in the region, women are represented in the agriculture sector more than men, and face additional restrictions in earning a living due to inequalities in access to land, productive inputs or to secure decent work in the sector. ${ }^{25}$ In Bangladesh, for example, 65 
percent of all employed women work in agriculture, compare to 40 percent of all employed men. ${ }^{26}$

The gender wage gap is a sign of persistent gender inequalities in Asia. Women's wages across the countries comprise between 70 and 90 percent of men's wages. ${ }^{27}$ The gender wage gap is caused by a number of factors including inequalities between men and women in the average seniority of their roles, the sectors that women are concentrated in being paid less on average, differences in working hours, and discrimination. Strikingly, the wage gap appears across all countries with data in Asia. In India, it stands at 32.6 percent, ${ }^{28}$ in Indonesia, 21.5 percent, and in Sri Lanka, 17.9 percent. $^{29}$

As well as being concentrated in low-paid sectors and roles, women also tend to earn less for doing the same types of jobs as men. In

Bangladesh, women earn an average of 23.1 percent less per hour than men for the same kind of jobs. ${ }^{30}$ In Pakistan in 2012, male agricultural workers earned $\$ 2.97$ per day while female agricultural workers earned $\$ 1.68$ per day.

Most countries in the region have signed International Labour Organization (ILO) conventions on equal pay and against discrimination, but few have passed legislation that specifically mandates equal pay for men and women. However, to achieve gender equality, changes in laws must also be accompanied by changes in social norms, which shape ideas about which roles men and women should do. Often a low value is placed on the roles traditionally seen as 'women's work', in particular that which can also be carried out in the home unpaid, for example cooking, cleaning, caring, tailoring and tending plants.

Poor employment conditions in the female-dominated manufacturing sectors are a challenge faced by millions of women in Asia on a daily basis. Women workers have to endure long working hours, psychological pressure and sexual harassment - and due to inadequate safety standards in many places of employment - a fear for their own health and lives. ${ }^{31}$

\section{UNPAID DOMESTIC AND CARE WORK}

Across all countries, women carry out the majority of unpaid domestic and care work, on average 2.5 times the amount that men do. ${ }^{32}$ This work includes activities such as cooking, cleaning, washing clothes, caring for dependants and fetching water and firewood. It is essential to the well-being and health of individuals, families, communities and economies, and for reproducing the labour force. However, it is not included in traditional measures of the economy, and often economic policies fail to recognize or invest in it, making inequalities worse. Research shows that poorer women tend to spend more of their time on unpaid care work than the richest women, and in countries with higher levels of economic inequality the difference is even wider. ${ }^{33}$ Even by conservative estimates, the time women spend on unpaid care work can be valued at $\$ 10$ trillion a year. ${ }^{34}$ 
Women's unequal responsibility for unpaid care work is a key determinant in the gendered nature of economic inequality. It creates 'time poverty', limiting women's choices and the time they have available for work, participation in public life and for rest or leisure time. It is also a strong contributory factor in women's lower rate of participation in the labour force, concentration in part-time work and lower wages. ${ }^{35}$ In South Asia, the gender pay gap increases from 14 percent to 35 percent for women living in households with children. ${ }^{36}$ And yet, when added together with paid work, women consistently do more or the same hours of total work that men do (see figure 3 ).

Inequalities in the share of unpaid care work are particularly stark in South Asia. In Bangladesh, for example, national time use surveys show women spend on average 3.6 hours a day on unpaid care and domestic work, compared to 1.4 hours for men. ${ }^{37}$ In Pakistan, women spend 4.3 more hours per day than men on this work. ${ }^{38}$ Oxfam's own research in Bangladesh has also shown that women spent less time on self care and sleeping than men. ${ }^{39}$ In focus group studies women reported an 84 hour work week, 16 percent more than men's 70 hours a week. The group estimated that women are paid for 31 percent of their work hours, while men are paid for 90 percent. ${ }^{40}$ Although women are spending equal or more hours than men working, the majority of this is not paid and goes unrecognized. As one participant noted:

'My daughter in law does most of the household chores with the assistance of [my] younger granddaughter, but we never asked my son to share household chores because it's our duty to take care of everyone, ${ }^{41}$

Figure 3: Total hours worked per day (paid and unpaid)

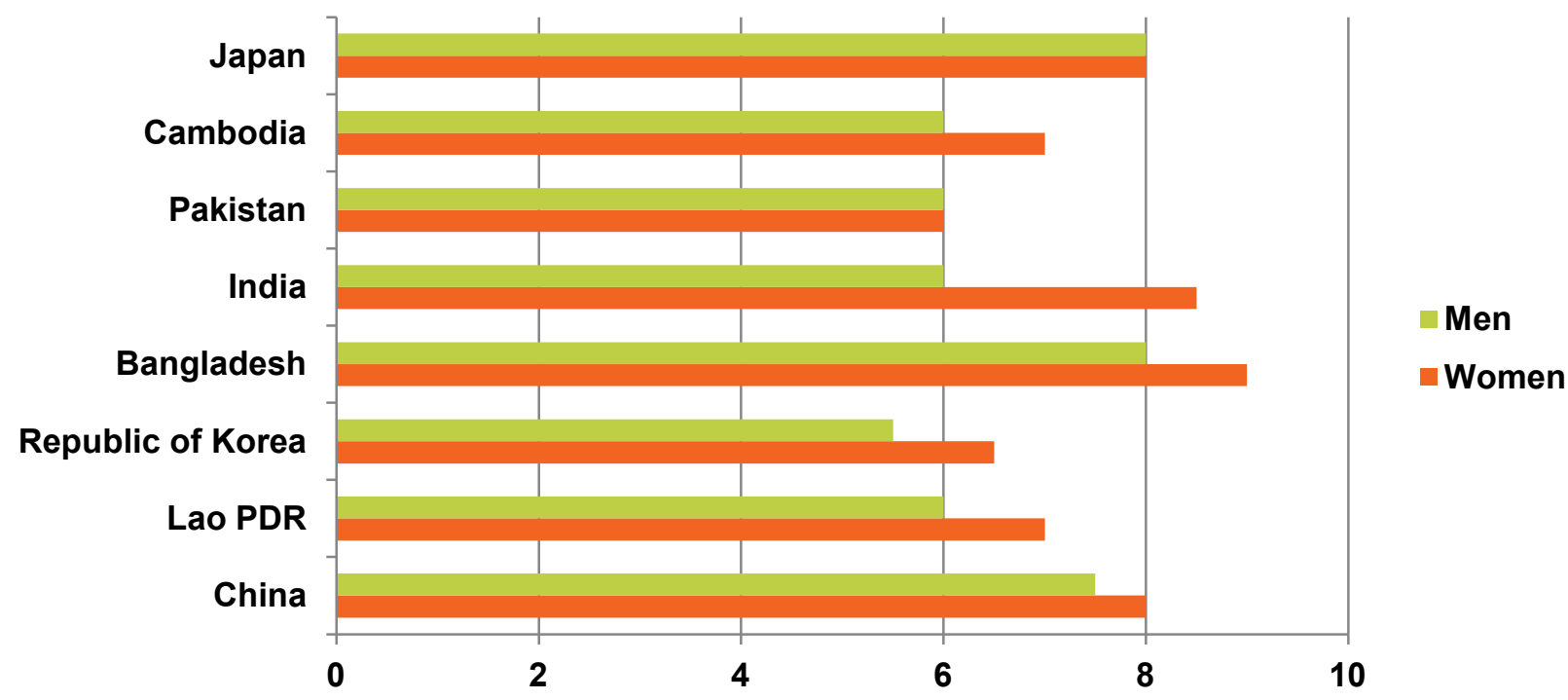

Source: Cambodia and Japan: OECD (2011), p.17. ${ }^{42}$ All other countries: UN Women (2015) ${ }^{43}$ 


\section{GENDER AND SOCIAL INEQUALITIES RESULT IN ECONOMIC INEQUALITIES}

If women are to gain economic equality, then the deep, structural gendered inequalities that lead to discrimination against women throughout society also need to be tackled. Negative social norms underpin gender inequality at all levels of society: the household, the workplace and institutions. These translate directly into economic inequalities for women. Women's roles are historically undervalued, which results in those roles being consistently paid less - this is particularly true of jobs in the care economy. ${ }^{44}$

The assumption that women should be less assertive and challenging about their employment conditions often means they are excluded from trade union or labour organization negotiations and find it more difficult to raise issues with management. Deep and persistent gender discrimination also results in violence against women and girls and lower levels of decision making power. Both of these need to be addressed alongside efforts to increase women's economic opportunities, if women are to benefit fairly from more economic engagement.

For many women, gender inequality in the economy is also exacerbated by the multiple layers of discrimination they experience. Inequalities driven by caste, class, non-indigenous and indigenous segments of society, and between rural and urban areas, can intersect and compound gender inequality. A study in 11 countries, for example, found that the application of minimum wage laws is lowest for women from ethnic minorities or indigenous groups. ${ }^{45}$ Other groups of women also consistently fail to benefit from minimum wage legislation: women employed in urban areas are usually in casual or temporary positions, or are self-employed, while those in rural areas normally work in agriculture where wages are low. ${ }^{46}$ In India, women in rural areas receive $\$ 2.21$ per day compared to men who earn $\$ 2.91$ per day. ${ }^{47}$ Just as the political, social and economic inequalities facing women in Asia need to be addressed together, so will governments across the region need to challenge these other forms of discrimination, if all are to benefit from increased access to economic opportunities.

\section{ACHIEVING EQUAL AND LIVING WAGES}

For over 70 years, the Universal Declaration of Human Rights has enshrined the right of every worker to a standard of living adequate for the health and well-being of themselves and their families. ${ }^{48}$ To achieve this standard, workers need to earn, in a standard week, a wage that meets their basic needs and provides some discretionary income to help improve their lives. Yet earning a living wage remains beyond the reach of many workers in Asia, particularly women, keeping millions locked in a 
cycle of poverty and debt. Without a living wage, women do not stand a chance of working their way out of poverty or achieving economic equality. Concentrated in low-paid roles, it is women who stand to gain the most from living wages, and their implementation can narrow gender pay gaps. ${ }^{49}$

The issue of low wages is a systemic one, closely related to precarious work and the excessive working hours which are so detrimental to the quality of life of workers and their families. Too often women's work involves long hours in poor conditions, and because wages are so low, workers seeking to support their families find themselves needing to borrow just to pay for the basics. ${ }^{50}$ Often jobs situated in profitable supply chains fail to result in workers lifting themselves out of poverty, no matter how hard they work. ${ }^{51}$

Figure 4: The road to a living wage

\begin{tabular}{|c|c|c|c|}
\hline \multicolumn{4}{|c|}{ THE ROAD TO A LIVING WAGE } \\
\hline \multicolumn{3}{|l|}{ UNSUSTAINABLE } & SUSTAINABLE \\
\hline $\begin{array}{l}\text { ILLEGAL ROAD } \\
\text { Does harm }\end{array}$ & $\begin{array}{l}\text { LOW ROAD } \\
\text { In-work poverty }\end{array}$ & $\begin{array}{l}\text { MEDIUM ROAD } \\
\text { Does some good }\end{array}$ & $\begin{array}{l}\text { HIGH ROAD } \\
\text { Does good }\end{array}$ \\
\hline $\begin{array}{l}\text { Forced labour, } \\
\text { denying workers their } \\
\text { human rights and } \\
\text { freedom. }\end{array}$ & $\begin{array}{l}\text { Subsistence wages } \\
\text { only. Work on legal } \\
\text { but low wages, } \\
\text { excessive hours, } \\
\text { often insecure. No } \\
\text { worker voice or } \\
\text { representation. }\end{array}$ & $\begin{array}{l}\text { Wages above the } \\
\text { legal minimum, with } \\
\text { secure contracts. } \\
\text { Workers have some } \\
\text { representation. }\end{array}$ & $\begin{array}{l}\text { Secure work on a } \\
\text { living wage, based on } \\
\text { a collective bargaining } \\
\text { agreement. }\end{array}$ \\
\hline \multicolumn{2}{|c|}{$\begin{array}{l}\text { The negative impact of a poverty wage: } \\
\text { 'I need to spend nearly } 2,000 \text { taka a month } \\
\text { for [my daughter's] education. I earn } 5,000 \\
\text { taka on average every month; out of this } \\
\text { money I have to give } 2,500 \text { taka for our food } \\
\text { and shelter to my uncle. After this nothing is } \\
\text { possible but to look out for more. I cannot } \\
\text { save up. } \\
\text { Garment worker in Bangladesh }\end{array}$} & \multicolumn{2}{|c|}{$\begin{array}{l}\text { The positive impact of a living wage: } \\
\text { 'I can now access nutritious food and I never } \\
\text { have to worry that I can't feed my family. I } \\
\text { have been able to send my daughter to } \\
\text { university and keep my son in high school - } \\
\text { this was always my dream. }{ }^{53} \\
\text { Maritza Vargas, president of the Alta Gracia } \\
\text { Union, Dominican Republic, in a factory } \\
\text { supplying the US student market. }\end{array}$} \\
\hline
\end{tabular}

Key factors that drive low wages include workers' weak collective power to bargain employment terms for themselves, the fact that the legal minimum wage in many countries falls well short of the cost of living, and the fact that prevailing business models are designed to maximize profits for the owners rather than the workers whose skills and labour made them possible. The strategy of developing countries in Asia basing their competitiveness in global markets on low wages has created downward pressure on women's wages and segregation into jobs with poor working conditions. $^{54}$ 
Case study 1: garment workers in Myanmar ${ }^{55}$

In Myanmar, the garment industry is growing rapidly, providing jobs for around 300,000 workers. In July 2015, research was conducted by Oxfam in Myanmar to understand workers' perspectives. ${ }^{56}$ Workers who participated in the survey (90 percent of whom were women) expressed concern about low wages, long hours and safety issues. Even with overtime, most said they could not afford housing, food and medicine with the income they earned at the factories.

Almost half of all respondents (43 percent) said they did not feel safe inside the factory. When asked why, they gave a range of reasons, with fire risk being the most prevalent. Workers reported that exit doors are often blocked with boxes and most said they would not know what to do in the event of a fire; 80 percent had never had any fire safety training.

The average base salary was found to be $\$ 1.50$ a day, and $\$ 40$ a month (Myanmar kyat (MMK) 49,400). ${ }^{57}$ An average worker spends 50 percent of their base wage on accommodation. Almost one-quarter of workers are the sole income earner in their family, with 95 percent reporting they support family members. Workers reported doing between 3 and 20 hours of overtime each week (10.5 hours on average). With this, and a complex system of bonuses, workers were able to boost their income to an average of $\$ 3.70$ a day ( $\$ 98$ per month/MMK 122,000).

Almost 40 percent said that overtime affected their health, with some commenting that they felt weak and lightheaded; there were reports of workers fainting, as in Cambodia. ${ }^{58}$ More than one in five (22 percent) reported forced overtime. Almost half of workers interviewed (43 percent) reported being in debt worth $\$ 46$ (MMK 57,400 ) on average. Nearly 90 percent said they had been unable to save any of their income.

\section{Ei Yin Mon's story}

'I arrived in Yangon after Cyclone Nargis in 2008 because there were no jobs after the cyclone. I wanted to be a school teacher, but failed year 10 and had to start working to support my family. My sister and I support our youngest sister who is still in high school and send money home to my mother who has diabetes and heart problems.

I don't want to keep working at the factory because the base wage is so low and we are pressured to do long hours of overtime. We are always being told to work faster. They think that we are like animals. I know I have no rights to make a complaint, so I have to bear it. I have been working here so many years and we try our best to meet the production targets so that we won't be told off, but sometimes it [the yelling] is unbearable.

We once had an accident and there was a fire in the factory. At that time, people were shouting at us to turn off the main switch. But we didn't know how to turn it off. We hadn't received any training or information about safety.'

\section{A WAGE TO LIVE ON?}

Although almost all countries in Asia have minimum wage laws and policies, workers across Asia experience two clear obstacles to benefiting from them. Firstly, minimum wage laws do not meet the goal of reducing poverty and inequality, because they have been set too low. This is especially true for poorer countries. Secondly, there is an 
overwhelming implementation failure to enforce these laws and to ensure that payment below the legal minimum wage, and other forms of wage theft, do not go unpunished.

\section{Box 2: Policies and laws on minimum wages across Asia}

In Pakistan, India, Indonesia and Sri Lanka, the government adopts and implements standalone policies on the minimum wage. In Pakistan, there are at least three policies on the minimum wage ${ }^{59}$ In India, the Minimum Wage Act of 1948 provided the mandate for government to establish floor wages in some sectors, and throughout the country. In China, Cambodia and Vietnam, there is no separate legislation on minimum wage, but the mandate for establishing this is drawn from provisions from broader labour legislation, or enforced through executive policies and ordinances. ${ }^{60}$

Myanmar, one of the last few countries in the region to establish this type of policy, finally approved its first minimum wage for workers in August 2015.

Paying living wages is not the same as paying the legal minimum wage. As Oxfam research has shown, even where legal minimum wages are in place, often these do not even cover the bare essentials for people working across a range of industries. For example, a study with the Ethical Tea Partnership in $2013^{61}$ concluded that in Assam, India, tea pluckers' wages left them below the World Bank poverty line of $\$ 1.90$ a day, despite in-kind benefits being provided and much of the tea being certified as socially responsible. Real living wages in Asia can be four times higher than the legal minimum wage (see figure 5).

\section{Box 3: Living wages - a definition}

A living wage, in short, means a wage that a worker and their family can live on - it includes enough for suitable housing, for education, for transport and for food - and it allows the worker to save a litte as well.

A living wage:

- Must be established in consultation with workers.

- Is sufficient to cover basic needs including food, housing, clothing, medical care, education, social relations, transportation and some savings.

- Includes enough for some discretionary income for unforseen events such as accidents or illness.

- Supports more people than just the individual worker - it is a family wage.

- Includes consideration of the number of hours needed to earn a living wage - not more than 48 hours per week.

- Includes strategies to periodically update rates, so that workers keep their relative purchasing power. 
Figure 5: Minimum wages versus living wages (as calculated by Asia Floor Wage)

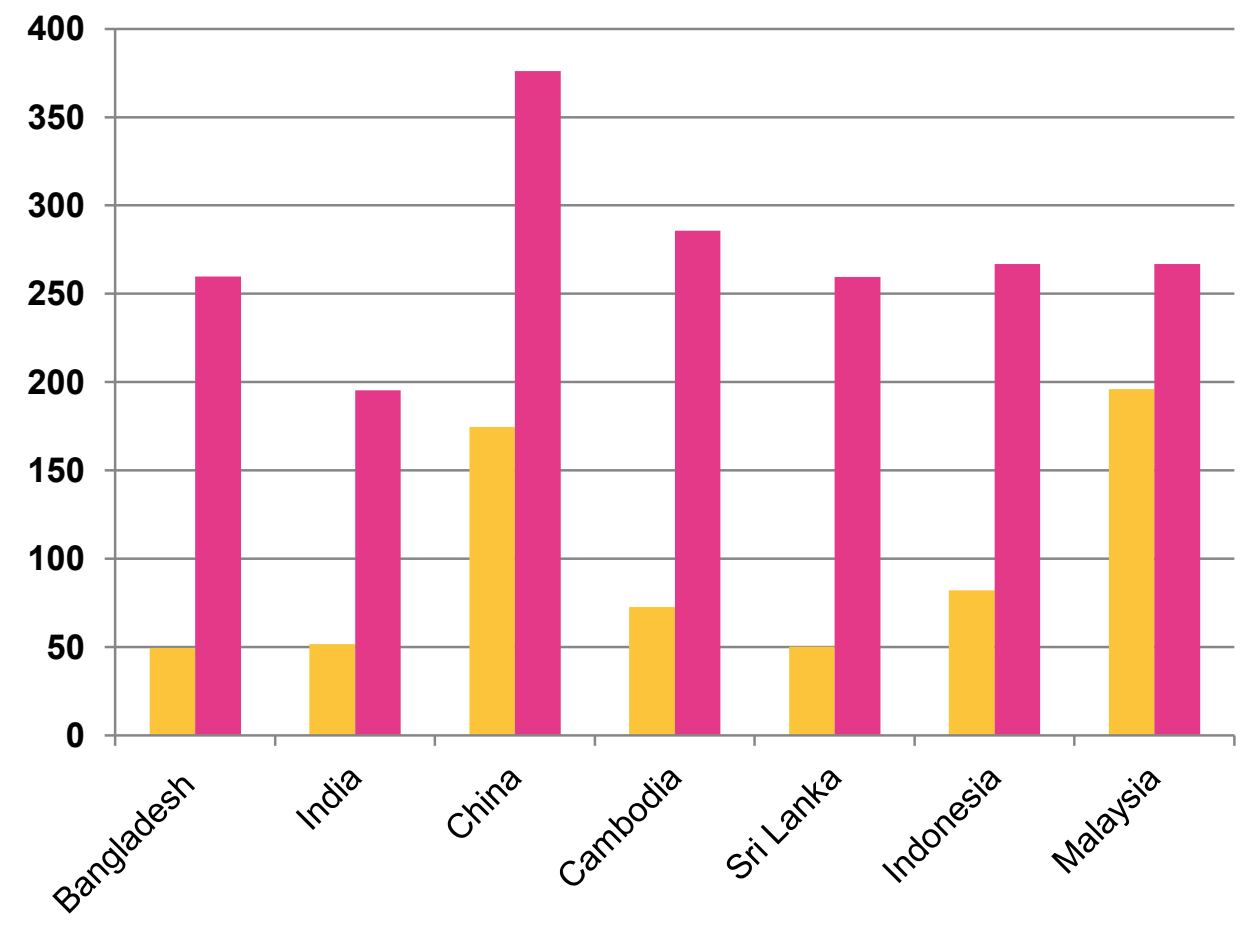

Minimum wage
(euros)

Living wage (euros)

Source: J. Merk (2014) Living Wage in Asia. Clean Clothes Campaign (2014) ${ }^{62}$

Once set low, minimum wages usually stay low: many governments fail to regularly adjust minimum wages - even though doing this would help workers keep their purchasing power as the cost of living rises. One study from 2013 shows that wages in Bangladesh, Mexico, Honduras, Cambodia and El Salvador declined in real value by an average of 14.6 percent during the period $2001-2011 .{ }^{63}$ One reason for this is that governments see low wages as necessary to remain competitive and attract foreign investment and buyers, creating a race to the bottom on wages and labour rights. Trade liberalization and the globalization of markets has enabled companies to put pressure on their supply chains to lower costs and to increase profits. The Clean Clothes Campaign notes that companies tend to move to countries that offer lower wages and working conditions, especially when workers in the country where they are operating start to call for fair compensation. ${ }^{64}$ It is this 'race to the bottom' that is behind the call for an Asia Floor Wage, which aims to establish a common wage for garment workers across the region, at levels that are sufficient for workers and their families to live decently. ${ }^{65}$

The second problem facing workers that depend on minimum wage legislation in Asia is the overwhelming implementation failure of these laws. Even though most countries have minimum wage laws, this is not always a guarantee that minimum wages are widely and consistently applied. Failure to properly implement wage policies results in illegal wage practices, which deprive workers of their legal entitlements and reduce take-home pay even more.$^{66}$ Critically for women, minimum wages may also not be applicable to many forms of women's work - for example unregistered agricultural work or work in the informal sector. Understanding how to extend minimum wages and social protections to 
these workers will be key to addressing inequality in women's work and wages across Asia.

\section{Minimum wages: a failure of implementation}

Even in sectors where a minimum wage is set, it is often not enforced.

For instance, a study on garment sector wages in ten Asian countries found that of 100 companies studied, more than half reported underpayment of wages, mostly of overtime, and almost half did not pay social security contributions. ${ }^{67}$

In Cambodia, government policy indicates that all enterprises should implement minimum wages. However, in reality, this is only implemented for those who work in the garments, textiles and shoe-sewing sector. ${ }^{68}$

In India, the law mandates the application of the minimum wage law throughout the country for specific occupations. However, it is implemented in such a way that the government is only required to set minimum wages for scheduled employments, or employments involving members of castes who suffer discrimination, in provinces where there are more than 1,000 people employed. ${ }^{69}$ In Vietnam, some progress has been made. Here, the minimum wage increased 67 percent in real terms between 2011 and 2015, as a result of government policy. However, it is only applicable to skilled workers in Ho Chi Minh City and Hanoi. If this wage were enforced and expanded to cover all workers, it would have the potential to benefit millions, with particular benefits for women.

Figure 6: Real wage growth in Vietnam

Real wage growth: Region 1 (Cu Chi/ HCM City) Minimum Wage



Source: Labour Rights in Vietnam: Unilever progress and systemic challenges (Oxfam, forthcoming $)^{70}$ 




Women's heavy and disproportionate responsibility for unpaid care work is a key barrier to their economic equality. This work is essential to the economy but is often not recognized, resulting in it often being left out of economic policy making and spending decisions. In order to address inequalities in unpaid care work, action must be taken to ensure that it is recognized, reduced and redistributed. ${ }^{71}$ Some of this can occur through social norm change which would encourage men to take on a higher responsibility. However success in achieving equality in care work also depends on the will of governments to raise enough revenue, particularly through progressive taxation, and invest it in infrastructure, social protection and public services.

\section{SOCIAL PROTECTION MEASURES}

Ensuring the adoption and implementation of laws on social protection is a crucial step that governments must take so that workers are cushioned, if not fully protected, from social and economic insecurities. This is critical for ensuring people's resilience to sharp and unexpected economic or other shocks, but putting these kinds of social protection policies in place will also support the reduction and redistribution of unpaid care work by, for example, supporting parental leave and basic income for older persons. Without these measures, it is predominantly women who will spend the time and meet the costs of caring for children or the elderly.

Box 4: ILO Social Protection Floors Recommendation, 2012 No. 202

The ILO recommends that national social protection floors should comprise at least the following social security guarantees, as defined at the national level:

- Access to essential health care, including maternity care.

- Basic income security for children, providing access to nutrition, education, care and any other necessary goods and services.

- Basic income security for persons in active age who are unable to earn sufficient income, in particular in cases of sickness, unemployment, maternity and disability.

- Basic income security for older persons. ${ }^{72}$

In Asia, the adoption and implementation of social protection measures vary greatly from one country to another. This is particularly evident within the Association of Southeast Asian Nations (ASEAN) where ASEAN Member States offer highly diverging levels of social protection. 
For instance, Thailand has at least one law for each of the social protection areas above, while Cambodia has operational legislation for only one social protection dimension. ${ }^{73}$ In 2013, ASEAN committed to undertake concrete actions to 'improve the quality, coverage and sustainability of social protection in ASEAN Member States. ${ }^{, 74}$

However, access to some forms of social protection (e.g. income security in cases of sickness, unemployment, maternity and disability) is often dependent on workers being employed in the formal sector, which means that women in the informal sector risk falling through the cracks. In South Asia, many people are self-employed, and wage workers and salaried employees account for only 20.8 percent of the workforce. ${ }^{75}$ Additionally, a large segment of wage earners are employed without formal contracts, as irregular, temporary or casual workers. Unfortunately, most of these are women and members of socially marginalized groups such as Dalits and other castes who suffer from discrimination. The absence of social protection makes them all the more vulnerable to exclusion and exploitation. ${ }^{76}$ The high levels of women - particularly in South-East Asia - employed in informal domestic work and care giving, is an additional dynamic severely limiting their access to social protection.

\section{PUBLIC SERVICES AND TAX JUSTICE}

The UN Special Rapporteur on Extreme Poverty and Human Rights described accessible, gender-sensitive public services as 'the most direct and effective way to redistribute [the poorest women's] heavy unpaid care workload and reduce its drudgery and intensity'. ${ }^{77}$ A progressive and fair tax system can enable the provision of essential public services which reduce gender inequality and redistribute unpaid care work, for example universal access to education, healthcare, drinking water and sanitation. ${ }^{78}$ For many of the poorest women and girls in Asia, day-to-day tasks such as cooking or collecting water or fuel take a disproportionate amount of time due to a lack of infrastructure and access to time- and labour-saving equipment. Improved access to infrastructure such as sanitation, electricity, clean water supplies and transport is shown to reduce time poverty for women and girls. ${ }^{79}$

Public investment in the care economy can create good quality jobs for women, reduce gender inequality and support economic growth. Research in seven OECD countries showed that if just two percent of GDP was invested in the care industry (in particular in social and childcare), employment would rise by an estimated 2.4 to 6.1 percent. ${ }^{80}$ The majority of the jobs created would likely be taken up by women, reducing gender gaps in employment, and the policies would boost overall employment and economic growth.

The tax systems in most Asian countries undermine the potential for these investments, inflicting fiscal injustices by providing privileges to the few (who are mostly men) and burdens for the majority (especially women). The capacity of governments to raise enough revenue to finance free, good quality public services has been subverted by a policy model which has prioritized attracting trade and investment through tax 
incentives - tax holidays, tax exemptions and free trade zones - over more progressive tax policies that can provide the revenue for vital inequality-reducing public services. In 2012, the share of central government revenue in GDP was 10.7 percent in South Asia and 10.9 percent in East Asia and the Pacific, compared with an average of close to 20 percent for Europe and central Asia. In the region, only Pakistan, the Philippines and India have corporate tax rates equal to 30 percent or more. ${ }^{81}$ This demonstrates that there is room for expanding fiscal space for social spending in many Asian economies.

At the same time, the global tax architecture is weakening the ability of governments to collect taxes and facilitating the concealment of wealth and cross-border tax dodging. A conservative estimate by Gabriel Zucman shows that $\$ 1.3$ trillion is hidden by wealthy individuals offshore away from tax authorities in Asia, depriving governments of \$34bn in revenues every year. ${ }^{82}$ When governments cannot raise enough revenue to fund investments in public services, they often rely instead on indirect taxation such as VAT on goods and services. Since the poorest pay a higher proportion of their income on these taxes they are considered regressive, and they also exacerbate gender inequalities because women are over-represented in lower income groups. ${ }^{83}$

\section{CONCLUSIONS}

Urgent measures are needed to tackle gender and other inequalities in Asia, which result in women's lower economic status. These include implementing living wages, increasing access to social protection, putting in place progressive tax policies that will finance good quality universal public services and recognizing, reducing and redistributing unpaid care work. These actions should take into account consideration of how to extend benefits to the informal economy where many women are concentrated.

Decent work, one of the Sustainable Development Goals, can be one of the principal solutions to growing inequality, if those in power drive the transformation of 'low road' jobs to 'high road' jobs. A transformation like this would have a particularly signficant impact on women currently concentrated in low-paid and insecure work. With active support from governments, companies and civil society, we can create a world where secure jobs on a living wage must become the norm, not the exception. 


\section{RECOMMENDATIONS}

The following are suggested actions for government and businesses to achieve living wages and address unpaid care work:

\section{Achieving equal and living wages}

\section{Governments could:}

- Assess current labour legislation and ensure genuine freedom of association and the rights of workers to have independent trade unions.

- Assess current wage standards to ensure domestic workers, migrant and informally employed workers are covered by all current and future labour standards legislation.

- Work through regional forums, such as ASEAN, to provide coordination of actions and to ensure that there is a level playing field that means countries do not undercut each other on:

- Lifting minimum wages.

- Ensuring coverage of homeworkers, migrant and informal workers by labour standards legislation.

- Ending the gender pay gap.

- Promoting positive social norms and attitudes to women's work.

\section{Governments and businesses could:}

- Commit to lifting minimum wages to living wage standards, setting out a roadmap to do so in consultation with workers and unions.

- Commit to end the gender pay gap, including through implementing legislation.

- Promote positive social norms and attitudes to women's work.

\section{Businesses could:}

- Ensure access to decent and safe employment opportunities for women, non-discrimination in the workplace, and women's right to organize.

- Ensure that the primary form of employment is permanent, openended and direct; any deviation from this norm should be justifiable, planned, limited and regulated.

- Recognize and respect the right of all workers to earn a living wage, and support and institute policies and practices to move towards living wages within their business, and at local, national and regional levels. 


\section{Recognizing, reducing and redistributing unpaid care work}

Governments could:

- Recognize the contribution of unpaid care work and help reduce the proportion borne by women through providing child and elderly care and paid family and medical leave, flexible working hours and paid parental leave.

- Adopt social protection measures which extend to migrant and informal workers, including: 1 . access to essential health and maternity care; 2 . basic income security for children; 3 . basic income security for workers in cases of sickness, unemployment, maternity and disability; and 4. basic income security for older persons.

- Invest in public services and infrastructure which reduces and redistributes unpaid care work, includng universal free public healthcare, water and sanitation.

- Increase their national tax to GDP ratio through progressive taxation, moving closer to maximum tax capacity to enable investment in the care economy.

- Improve data collection on the distribution of unpaid care work, in order to measure SDG target $5.4^{84}$ and also to recognize the contribution unpaid care work makes to the economy.

- Systematically analyse proposed economic policies for their impact on girls and women; improve data in national and accounting systems including below the household level - to monitor and assess this impact (including on the distribution of unpaid care work).

- Priortize gender-budgeting ${ }^{85}$ to assess the impact of spending decisions on women and girls, and allocate resources in ways that promote gender equality.

\section{Businesses could:}

- Recognize unpaid care work, and seek to reduce and redistribute it through supporting flexible working, parental leave and the provision of care facilties such as childcare. 
1 ILO Regional Office for Asia and the Pacific and Asian Development Bank (2011) Women and labour markets in Asia : rebalancing towards gender equality in labour markets in Asia. Bangkok: ILO. Retrieved 9th May, from http://www.ilo.org/wcmsp5/groups/public/--asia/---ro-bangkok/documents/publication/wcms_154846.pdf

2 UN Women (2015) Progress of the World's Women 2015-2016: Transforming Economies, Realizing Rights. Retrieved 9 May 2016, from http://progress.unwomen.org/en/2015/pdf/UNW_progressreport.pdf

3 McKinsey \& Company. (2015). The Power of Parity. Retrieved May 9th 2016, from http://www.mckinsey.com/global-themes/employment-and-growth/how-advancingwomens-equality-can-add-12-trillion-to-global-growth

4 Sonali Jain-Chandra, Tidiane Kinda, Kalpana Kochhar, Shi Piao and Johanna Schauer. (2016). Sharing the Growth Dividend: Analysis of Inequality in Asia. IMF Working Paper, Asia and Pacific Department. Retrieved 9 May 2016, from https://www.imf.org/external/pubs/ft/wp/2016/wp1648.pdf

$5 \mathrm{lbid}$.

6 lbid.

7 lbid.

8 D. Hardoon, R. Fuentes-Nieva and S. Ayele. (2016). An Economy for the 1\%. Oxford: Oxfam. Retrieved 9 May 2016, from https://www.oxfam.org/en/research/economy-1

9 S. Akhter (2014) Endless Misery of Nimble Fingers: The Rana Plaza Disaster. Asian Journal for Women's Studies, Vol. 20 No. 1, 2014, pp. 137-147 Retrieved 9 May 2016 from http://www.adpc.net/igo/category/ID596/doc/2014-pul8Ob-ADPC-

ADPC_paper_on_women.pdf

10 Asian Development Bank. (2015). Women in the workforce: An unmet potential in Asia and the Pacific. Mandaluyong City, Philippines: Asian Development Bank. Retrieved 9 May 2016, from http://www.adb.org/publications/women-workforce-unmet-potential-asiaand-pacific

11 C. Gonzales et al. (2015). Catalyst for Change: Empowering Women and Tackling Income Inequality. IMF. Retrieved 9 May 2016, from http://www.imf.org/external/pubs/ft/sdn/2015/sdn1520.pdf

12 UNOHCHR (2011) Guiding Principles on Business and Human Rights Implementing the United Nations 'Protect, Respect and Remedy' Framework. New York and Geneva: United Nations. Retrieved 9 May 2016, from http://www.ohchr.org/Documents/Publications/GuidingPrinciplesBusinessHR_EN.pdf

13 ETI Denmark, Norway and UK (2015) Living wages in global supply chains: A new agenda for business. Retrieved 9 May 2016, from http://www.ethicaltrade.org/resources/living-wages-in-global-supply-chains-new-agendabusiness

14 Sustainable Development Goals, Goal 5,Goal 8 and Goal 10, available at https://sustainabledevelopment.un.org/?menu=1300 Retrieved 9 May 2016.

15 World Bank (2016) Women, Business and the Law: Dataset, available from http://wbl.worldbank.org/. Retrieved 18 May 2016.

16 Asian Development Bank. (2015). Women in the workforce.

17 K. Donald and R. Moussié. (2016) Redistributing Unpaid Care Work: Why Tax Matters For Women's Rights. Retreived 9 May 2016, from http://www.ids.ac.uk/publication/redistributing-unpaid-care-work-why-tax-matters-forwomen-s-rights

18 ILO STAT database, accessed 9 May 2016

https://www.ilo.org/ilostat/faces/oracle/webcenter/portalapp/pagehierarchy/Page137.jspx ?_afrLoop=104527323335610\&clean=true

19 See ILO definition of employment.

20 Source: ILO STAT Employment by sex and age (ILO estimates and projections) 2015 http://www.ilo.org/stat/lang--en/index.htm

21 Y. Meulen Rodgers and J. E. Zveglich, Jr. (2012). Inclusive Growth and Gender Inequality in Asia's Labor Markets. Asian Development Bank. Retreived 9 May 2016, from http://www.adb.org/sites/default/files/publication/30137/economics-wp321 inclusive-growth-gender-inequality.pdf 
22 lbid.

23 Ibid.

24 UN Women (2015) Progress of the World's Women 2015-2016: Transforming Economies, Realizing Rights.

25 Y. Meulen Rodgers and J. E. Zveglich, Jr. (2012). Inclusive Growth.

26 World Bank World Development Indicators. Retrieved 19 May from http://data.worldbank.org/data-catalog/world-development-indicators

27 ILO Regional Office for Asia and the Pacific and Asian Development Bank (2011) Women and labour markets in Asia : rebalancing towards gender equality in labour markets in Asia. Bangkok: ILO. Retrieved 9th May, from http://www.ilo.org/wcmsp5/groups/public/---asia/---robangkok/documents/publication/wcms_154846.pdf

28 ILOSTAT database, India country profile, retrieved 21 April 2016, from http://www.ilo.org/ilostat/faces/home/statisticaldata/ContryProfileld?_afrLoop=89209316 4297035\#\%40\%3F_afrLoop\%3D892093164297035\%26_adf.ctrlstate\%3Dcxhpmm6ㅎ﹎_4

29 ILOSTAT database, Sri Lanka country profile, retrieved 21 April 2016, from http://www.ilo.org/ilostat/faces/home/statisticaldata/ContryProfileld?_afrLoop=89209316 4297035\#\%40\%3F_afrLoop\%3D892093164297035\%26_adf.ctrlstate\%3Dcxhpmm66r_4

30 S. Kapos (2008) The gender wage gap in Bangladesh: ILO Asia-Pacific Working Paper Series. ILO. Retrieved 9 May 2016, from http://www.ilo.org/wcmsp5/groups/public/@asia/@robangkok/documents/publication/wcms_098063.pdf

31 S. Akhter. (2014). Endless Misery of Nimble Fingers.

32 UN Women (2015) Progress of the World's Women 2015-2016: Transforming Economies, Realizing Rights. Retrieved 9 May 2016, from http://progress.unwomen.org/en/2015/pdf/UNW_progressreport.pdf

33 S. Gupta et. al (2010). Economic Inequality and Housework in Economic inequality, pp.105-122 in Housework Dividing the Domestic. Men, Women and Household Work in Cross-National Perspective, edited by Judy Treas and Sonia Drobnic. Stanford: Stanford University Press.

34 McKinsey \& Company. (2015). The Power of Parity.

The value should be taken as a conservative estimate since it is calculated using minimum wages. The cost of supplying this care professionally and the opportunity cost of women not working while they are caring are likely to be much higher than minimum-wage levels.

35 McKinsey \& Company. (2015). The Power of Parity.

36 UN Women (2015) Progress of the World's Women 2015-2016.

37 Ibid.

38 lbid.

39 M.B Akhter, Shamema Akther Shamme (2015) Exploring Unpaid Care Work of Women: Barriers, Implications \& Opportunities Oxfam (unpublished).

40 G. F. Rabbani (2014) Bangladeshi women speak up about care and cooking. Policy and Practice Blog, Oxfam GB, published 22 October 2015, Retrieved 19 May from http://policy-practice.oxfam.org.uk/blog/2014/10/investing-in-fuel-efficient-stoves-toreduce-unpaid-care-in-bangladesh

41 M.B Akhter, Shamema Akther Shamme (2015) Exploring Unpaid Care Work of Women. 42 OECD. (2011). Society at a Glance - Asia/Pacific Edition. Paris: OECD. P.17.

43 UN Women (2015) Progress of the World's Women 2015-2016.

44 D. Perrons. (2015). Gendering the Inequality Debate. Gender and Development 23(2), 218.

45 ILO (2015) Indigenous People in the World of Work, Snapshots from Asia, International Labor Organization. Geneva: ILO. Retrieved May 9th 2016, from http://www.ilo.org/gender/Informationresources/Publications/WCMS_389366/lang-en/index.htm

46 R. Nayar et. Al. (2011) More and Better Jobs in South Asia. Washington D.C.: World Bank. Retrieved May 9th 2016, from http://www.worldbank.org/en/region/sar/publication/flagship-more-and-better-jobs-insouth-asia

47 Y. Meulen Rodgers and J. E. Zveglich, Jr. (2012). Inclusive Growth. 
48 ILO Constitution, Retrieved 19 May 2016 from

http://www.ilo.org/dyn/normlex/en/f?p=1000:62:0::NO:62:P62_LIST_ENTRIE_ID:24539

07:NO

49 UN Women (2015) Progress of the World's Women 2015-2016.

50 Gardner, D. And Burnley, J. (2015) Made in Myanmar: Entrenched poverty or decent jobs for garment workers. Oxford: Oxfam International. Retrieved 9 May 2016, from http://policy-practice.oxfam.org.uk/publications/made-in-myanmar-entrenched-povertyor-decent-jobs-for-garment-workers-583241

51 R. Wilshaw, S. Hamiton, J. Théroux-Séguin and D. Gardener (2015) In Work but Trapped in Poverty: A Summary of Five Studies Conducted by Oxfam, With Updates on Progress Along the Road to a Living Wage. Oxford: Oxfam. Retrieved 9 May 2016, from http://policy-practice.oxfam.org.uk/publications/in-work-but-trapped-in-poverty-asummary-of-five-studies-conducted-by-oxfam-wit-578815

52 War on Want (2013) The Living Wage: Winning the Fight for Social Justice. Retrieved 18 May 2016 from

http://media.waronwant.org/sites/default/files/The\%20Living\%20Wage\%20-

\%20War\%20on\%20Want.PDF?_ga=1.194517994.619200909.1463590809

53 R. Wilshaw, S. Hamiton, J. Théroux-Séguin and D. Gardener (2015). In Work but Trapped in Poverty.

54 Y. Meulen Rodgers and J. E. Zveglich, Jr. (2012) Inclusive Growth.

55 Gardner, D. And Burnley, J. (2015) Made in Myanmar.

56 Ibid.

57 MMK to USD exchange rate is based on the exchange rate at 30 July 2015 $\mathrm{http}: / / \mathrm{www}$.oanda.com/currency/converter/ figures have been rounded to the closest decimal.

58 No author (2015, Nov 6) One garment worker dies, 21 faint at Cambodian factory. The Strait Times. Retrieved 9 May 2016, from http://www.straitstimes.com/asia/se-asia/onegarment-worker-dies-21-faint-at-cambodian-factory

59 These policies are: The Minimum Wages Ordinance of 1961; the West Pakistan Minimum Wages for Unskilled Workers Ordinance of 1969; and the Minimum Wages Rule of 1982 (which is essentially a promulgation of the Minimum Wages Ordinance of 1961). Minimum Wage Comparison: Asian Countries, Wage indicator Minimum Wage Report Series 01, June 2012, available at http://www.wageindicator.org/documents/publicationslist/publications-

2012/120627Minimum\%20Wage\%20Comparison_Asian\%20Countries_Representation. pdf

60 For example, in Vietnam, the Labour Code of 1994 covers all labour related regulations, including the setting up of minimum wages. In China, the Ministry of Labour and Employment promulgated the Provision for Minimum Wage, which gave it the mandate to establish wage levels in different provinces and regions.

61 Oxfam International and Ethical Tea Partnership (2013) Understanding Wage Issues in the Tea Industry. Oxfam International and Ethical Tea Partnership. Retrieved 24 May 2016 from http://policy-practice.oxfam.org.uk/publications/understanding-wage-issuesin-the-tea-industry-287930

62 J. Merk (2014) Living Wage in Asia. Clean Clothes Campaign. Retrieved 9 May 2016, from http://www.cleanclothes.org/resources/publications/asia-wage-report/view

63 Workers Rights Consortium (2013) Global Wage Trends for Apparel Workers, 2001 2011. Workers Rights Consortium. Retrieved 9 May 2016, from http://cdn.americanprogress.org/wp-content/uploads/2013/07/RealWageStudy-3.pdf

64 Why an Asia Floor Wage? Retrieved 9 May 2016 from Clean Clothes Campaign website http://www.cleanclothes.org/livingwage/what-is-the-asia-floor-wage

$65 \mathrm{lbid}$.

66 J. Merk (2014) Living Wage in Asia.

67 ILO (2014) Wages and working hours in the textiles, clothing, leather and footwear industries. Geneva: ILO. Retrieved May 9th, from

http://www.ilo.org/wcmsp5/groups/public/@ed_dialogue/@sector/documents/publication /wcms_300463.pdf

68 Minimum Wage Comparison: Asian Countries. Wage indicator Minimum Wage Report

Series 01, June 2012. Available at

http://www.wageindicator.org/documents/publicationslist/publications-

2012/120627Minimum\%20Wage\%20Comparison_Asian\%20Countries_Representation. pdf

$69 \mathrm{lbid}$. 
70 Oxfam (forthcoming) Labour Rights in Vietnam: Unilever's Progress and Systemic Challenges. Oxford: Oxfam.

71 The model 'Recognize, Reduce and Redistribute', relating to unpaid care work, was conceived by Professor Diane Elson.

72 These provisions are enumerated in the ILO Social Protection Floors Recommendation, 2012 No. 202, available at

http://www.ilo.org/dyn/normlex/en/f?p=NORMLEXPUB:12100:0::NO::P12100_ILO_COD

E:R202 This recommendation identified nine main areas of social security, which include medical care, sickness, unemployment, old age, employment injury, family, maternity, invalidity and survivors' benefits. See- International Labour Standards on Social Security, ILO Website, available at http://www.ilo.org/global/standards/subjectscovered-by-international-labour-standards/social-security/lang--en/index.htm

73 C. Boon Ong and C. Peyron Bista (2015) The state of social protection in ASEAN at the dawn of integration. Bangkok: ILO Regional Office for Asia and the Pacific. Retrieved 9 May 2016, from http://www.ilo.org/wcmsp5/groups/public/---asia/---ro-bangkok/---ilojakarta/documents/publication/wcms_428982.pdf

74 ASEAN Declaration on Strengthening Social Protection, ASEAN website, retrieved 9 May 2016, from

http://www.asean.org/storage/images/archive/23rdASEANSummit/5.\%20asean $\% 20 \mathrm{decl}$ aration\%20on\%20social\%20protection_final.pdf

75 S. Pratap (2014) Towards a regional social protection for South Asia - a framework for discussion. Asian Monitoring Resource Center, Retrieved 9 May 2016, from http://www.amrc.org.hk/content/towards-regional-social-protection-south-asiaframework-discussion-2014

76 Ibid.

77 M. Sepúlveda Carmona (2013) Report of the Special Rapporteur on extreme poverty and human rights: unpaid care work, poverty and women's human rights, UN Doc $\mathrm{A} / 68 / 293$;

78 K. Donald and R. Moussié. (2016) Redistributing Unpaid Care Work.

79 Asian Development Bank (2015). Desk review of women's time poverty and infrastructure in Asia and the Pacific. Mandaluyong City, Philippines: Asian Development Bank. Retrieved 9 May 2016, from http://www.adb.org/sites/default/files/publication/177465/sdcc-balancing-burden.pdf

$80 \mathrm{~J}$. De Henau. Et. al (2016). Investing in the Care Economy: A gender analysis of employment stimulus in seven OECD countries. Report by the UK Women's Budget Group for the International Trade Union Confederation, Brussels. Retrieved 9 May, from http://www.ituc-csi.org/CareJobs?lang=en

81 KPMG Corporate Tax Rates Table. Retrieved 18 May 2016 from https://home.kpmg.com/xx/en/home/services/tax/tax-tools-and-resources/tax-ratesonline/corporate-tax-rates-table.html

82 G. Zucman (2015) The Hidden Wealth of Nations. Pg. 53. University of Chicago Press

83 F. Rhodes (2016) Women and the 1\%: How extreme economic inequality and gender inequality must be tackled together. Oxford: Oxfam International. Retrieved 19 May from https://www.oxfam.org/en/research/women-and-1

84 Sustainable Development Goals, Target 5.4, available at https://sustainabledevelopment.un.org/?menu=1300 Retrieved 9 May 2016.

85 Gender-responsive budgeting is a process designed to incorporate gender dimensions in all stages of the budget cycle. For further information on how this works in practice please see J. Burnley, P. Ei Phyu and M. Hilton (2016) A Case for Gender-Responsive Budgeting in Myanmar. Oxfam GB, ActionAid, Care, Women's Organisations' Network, Retrieved 24 May 2016 from http://policy-practice.oxfam.org.uk/publications/a-case-forgender-responsive-budgeting-in-myanmar-603484 
This paper was written by Francesca Rhodes, Jasmine Burnley, Maria Dolores, Joy Kyriacou, Rachel Wilshaw, Daria Ukhova, Luke Gibson and Mustafa Talpur. It is part of a series of papers written to inform public debate on development and humanitarian policy issues.

For further information on the issues raised in this paper please email advocacy@oxfaminternational.org

This publication is copyright but the text may be used free of charge for the purposes of advocacy, campaigning, education, and research, provided that the source is acknowledged in full. The copyright holder requests that all such use be registered with them for impact assessment purposes. For copying in any other circumstances, or for reuse in other publications, or for translation or adaptation, permission must be secured and a fee may be charged. Email policyandpractice@oxfam.org.uk.

The information in this publication is correct at the time of going to press.

Published by Oxfam GB for Oxfam International under ISBN 978-0-85598-736-7 in June 2016.

Oxfam GB, Oxfam House, John Smith Drive, Cowley, Oxford, OX4 2JY, UK.

\section{OXFAM}

Oxfam is an international confederation of 20 organizations networked together in more than 90 countries, as part of a global movement for change, to build a future free from the injustice of poverty. Please write to any of the agencies for further information, or visit www.oxfam.org. 